\title{
Does the principal's leadership contribute to teacher job satisfaction at school?
}

\author{
Nellitawati Nellitawati \\ Universitas Negeri Padang
}

\begin{abstract}
The purpose of this study was to analyze the contribution of principals' leadership to teacher job satisfaction. Using quantitative correlational research methods, which will reveal the contribution of each variable. The research sample was 86 teachers. Data collection used two instruments, namely the teacher's job satisfaction questionnaire and the principal's leadership questionnaire. Data analysis techniques using simple regression and correlation techniques. The results showed that the principal's leadership significantly contributed to teacher job satisfaction. It can be concluded that the Principal's leadership is one of the most important factors because it can affect teacher job satisfaction. So that improving the quality of leadership by school principals needs to be improved.
\end{abstract}

Keywords: Principals leadership, teacher job satifaction

This is an open access article distributed under the Creative Commons Attribution License, which permits unrestricted use, distribution, and reproduction in any medium, provided the original work is properly cited. C2019 by author

\section{INTRODUCTION}

Teachers play an important role in carrying out learning in schools, almost all aspects of learning are influenced by teacher performance (Elliott, 2015; Harris \& Sass, 2014). Teachers who have good work results will produce good quality education too, so improving teacher performance needs to get a lot of attention from various parties (Andriani, Kesumawati, \& Kristiawan, 2018). A teacher in carrying out his duties and responsibilities as an educator displays many attitudes towards his work, whether it is a negative attitude or a positive attitude. The attitude displayed is closely related to job satisfaction.

Job satisfaction is an individual thing, because each individual has a different level of satisfaction, according to the values that apply in each individual (Altaf \& Awan, 2011). The more aspects of work are under individual desires, the higher the level of job satisfaction received. Job satisfaction is a feeling that supports or does not in employees associated with work or personal needs. According to (Wibowo, Riana, \& Putra, 2015) job satisfaction is an attitude towards someone's job that determines the difference between the number of awards received by workers and the amount they believe should be received. Bahri defines job satisfaction as a pleasant emotion and appreciates his work (Bahri \& Nisa, 2017). In line with Zulkifli's opinion which states that job satisfaction can be interpreted as a complex emotional reaction, where this emotional reaction results from encouragement, desire, recovery and employee expectations for work supported by reality, giving rise to feelings of pleasure, satisfaction or feeling dissatisfied (Zulkifli, Darmawan, \& Sutrisno, 2014).

Gibson defines job satisfaction as a positive or negative attitude that an individual has towards various aspects of work, workplace, and relationships with colleagues (Celik, 2011; Gibson \& Petrosko, 2014). Job satisfaction is not a simple thing, both in the concept's sense and in the analysis's sense because job satisfaction has various connotations (Ferguson, Frost, \& Hall, 2012; Skaalvik \& Skaalvik, 2011). It is understood that someone with a top-level of job satisfaction will show a positive attitude towards their work, whereas someone dissatisfied with their work will show a negative attitude towards their work.

A stable and pleasant emotional condition is needed by a teacher so that his tasks and responsibilities can be carried out well. If the teacher is satisfied with his work, he will do his duties and responsibilities well. Excellent work results will affect the improvement and productivity of an organization. This is supported by 
Sutrisno (2010: 75) who argues that job satisfaction can increase one's enthusiasm and activeness to work better.

Given the importance of teacher job satisfaction under their role as agents of learning in all educational programs in schools, the role of school leadership is an important factor (Aydin, Sarier, \& Uysal, 2013; Menon, 2014). The principal's leadership must be able to create conditions that allow the job satisfaction of teachers (Saleem, 2015). As an education leader in a school, the principal has a legal responsibility to develop the staff, curriculum, and implementation of education in his school. Here, the effectiveness of principals' leadership depends on their ability to relate to teachers and staff, and their ability to control budgets, staff development, scheduling, curriculum development, pedagogy, and assessors.

The phenomena found in some schools were job satisfaction, problems including teachers complaining because the work environment was uncomfortable, personal communication was less comfortable, teacher incentives were less noticed, principals were more demanding for teachers, low work performance, and low quality of teaching. Then another phenomenon that is seen is that school principals are less able to carry out their leadership duties. Principals who are less able to communicate with teachers, and staff. Because it is necessary to analyze the principal's contribution to teacher satisfaction.

\section{METHOD}

This study uses a quantitative correlational method (Apuke, 2017), which will reveal the contribution of each variable. The research sample was 86 teachers. Data collection uses two instruments, the teacher job satisfaction questionnaire, and the principal's leadership questionnaire. Both questionnaires used have been tested for validity and reliability. Data analysis techniques using simple regression and correlation techniques with the help of SPSS version 20.00 .

\section{RESULT AND DISCUSSION}

The following describes the results of the calculation of the correlation coefficient of principals' leadership and teacher job satisfaction, the results of the analysis can be seen in Table 1.

Table 1. Results of the correlation analysis between the principal's leadership variables and teacher job satisfaction.

\begin{tabular}{ccccc}
\hline correlation & $\begin{array}{c}\text { Correlation } \\
\text { coefficient }(\mathbf{r})\end{array}$ & $\begin{array}{c}\text { Coefficient of } \\
\text { Determination }\left(\mathbf{r}^{\mathbf{2}}\right)\end{array}$ & Contribution & $\mathbf{P}$ \\
\hline $\mathbf{r x y}_{\mathbf{1}}$ & 0.188 & 0.036 & $3.6 \%$ & 0.001 \\
\hline
\end{tabular}

Table 1 shows that the correlation coefficient (ry1) $=0.188$ and $\rho=0.001<0.05$. This means that the principal's leadership contributes to teacher job satisfaction. The magnitude of the coefficient of determination $\left(\mathrm{r}^{2}\right)$ of 0.036 . To determine the form of predictive relationships or between the principal's leadership and teacher job satisfaction, a simple regression analysis was performed. From the regression analysis results got by the regression equation $\hat{Y}=111.266+0.169$. This equation is then tested for significance. Calculation results can be seen in Table 2 .

Table 2. Results of regression analysis of school leadership variables and teacher job satisfaction

\begin{tabular}{|c|c|c|c|c|c|}
\hline Source & Sum of quadrate & Dk & $\begin{array}{c}\text { Average } \\
\text { Sum of quadrate }\end{array}$ & $\overline{F_{\text {count }}}$ & $\bar{P}$ \\
\hline Regression & 65.956 & 1 & 65.956 & 3.093 & 0.001 \\
\hline Residue & 1791.497 & 84 & 21.327 & & \\
\hline Total & 1857.453 & 85 & & & \\
\hline
\end{tabular}

The results from Table 2 above show that Fcount $=3.093$ with $\rho=0.001<\alpha 0.05$. this means the regression equation is significant in the $95 \%$ confidence level and can predict teacher job satisfaction. 
Next, the significance of the regression coefficient test is performed. The results of the analysis can be seen in Table 3.

Table 3. Test results for the principal leadership regression coefficient on teacher job satisfaction

\begin{tabular}{lllll}
\hline \multicolumn{1}{c}{ Source } & \multicolumn{1}{c}{ Coefficient } & T & Sig. \\
\hline Constant & 111.266 & 10.175 & 0.000 \\
Principal's Leadership & .169 & 1.759 & 0.001 \\
\hline
\end{tabular}

The regression equation explains that $\hat{\mathrm{Y}}=111,266+0.169 \mathrm{X}$ each increase in principal leadership by 1 scale will contribute to the increase in principal leadership by 0.169 scales. While the teacher job satisfaction score is 111,266 scale without the leadership of the principal.

Based on the results of the tests that have been carried out, all are significant, it can be concluded that the principal's leadership contributes to teacher job satisfaction (Aydin, et al., 2013; Van Maele \& Van Houtte, 2012). It can be interpreted that the principal's leadership factor has significant predictive power on teacher job satisfaction (Aldridge \& Fraser, 2016; Lee \& Nie, 2014). The contribution of the principal's leadership to teacher job satisfaction is $3.6 \%$.

The results of the data analysis of this study show that the principal's leadership variables contribute to teacher job satisfaction. The magnitude of the variable contribution to teacher job satisfaction by $5.9 \%$, the remaining $80.6 \%$ is the contribution of other variables that also influence teacher satisfaction not examined in this study because of the limitations of the author.

Data analysis shows that teacher job satisfaction is significantly influenced by the principal's leadership and the teacher's responsibility both individually and together (Alonderiene \& Majauskaite, 2016; Shaw \& Newton, 2014). Principal's leadership is one very important factor because it can affect teacher job satisfaction. So that improving the quality of leadership by school principals needs to be improved.

\section{CONCLUSION}

Principal's leadership is not the only factor that contributes to teacher job satisfaction, but the results of the study show that the principal's leadership contributes significantly to teacher job satisfaction, therefore the principal must continue to improve the quality of his leadership.

\section{REFERENCES}

Aldridge, J. M., \& Fraser, B. J. (2016). Teachers' views of their school climate and its relationship with teacher self-efficacy and job satisfaction. Learning Environments Research, 19(2), 291-307.

Alonderiene, R., \& Majauskaite, M. (2016). Leadership style and job satisfaction in higher education institutions. International Journal of Educational Management.

Altaf, A., \& Awan, M. A. (2011). Moderating affect of workplace spirituality on the relationship of job overload and job satisfaction. Journal of business ethics, 104(1), 93-99.

Andriani, S., Kesumawati, N., \& Kristiawan, M. (2018). The Influence of the Transformational Leadership and Work Motivation on Teachers Performance. International Journal of Scientific \& Technology Research, 7(7), 19-29.

Apuke, O. D. (2017). Quantitative research methods: A synopsis approach. Kuwait Chapter of Arabian Journal of Business and Management Review, 33(5471), 1-8.

Aydin, A., Sarier, Y., \& Uysal, S. (2013). The Effect of School Principals' Leadership Styles on Teachers' Organizational Commitment and Job Satisfaction. Educational sciences: Theory and practice, 13(2), 806-811.

Bahri, S., \& Nisa, Y. C. (2017). Pengaruh Pengembangan Karir Dan Motivasi Kerja Terhadap Kepuasan Kerja Karyawan. Jurnal Ilmiah Manajemen dan Bisnis, 18(1), 9-15.

Celik, M. (2011). A theoretical approach to the job satisfaction. Polish journal of management studies, 4, 7-14.

Elliott, K. (2015). Teacher Performance Appraisal: More about Performance or Development? Australian Journal of teacher education, 40(9), n9.

Ferguson, K., Frost, L., \& Hall, D. (2012). Predicting teacher anxiety, depression, and job satisfaction. Journal of teaching and learning, $8(1)$. 
Gibson, D., \& Petrosko, J. (2014). Trust in leader and its effect on job satisfaction and intent to leave in a healthcare setting. New Horizons in Adult Education and Human Resource Development, 26(3), 3-19.

Harris, D. N., \& Sass, T. R. (2014). Skills, productivity and the evaluation of teacher performance. Economics of Education Review, 40, 183-204.

Lee, A. N., \& Nie, Y. (2014). Understanding teacher empowerment: Teachers' perceptions of principal's and immediate supervisor's empowering behaviours, psychological empowerment and work-related outcomes. Teaching and teacher education, 41, 67-79.

Menon, M. E. (2014). The relationship between transformational leadership, perceived leader effectiveness and teachers' job satisfaction. Journal of Educational Administration.

Saleem, H. (2015). The impact of leadership styles on job satisfaction and mediating role of perceived organizational politics. Procedia-Social and Behavioral Sciences, 172(27), 563-569.

Shaw, J., \& Newton, J. (2014). Teacher retention and satisfaction with a servant leader as principal. Education, 135(1), 101-106.

Skaalvik, E. M., \& Skaalvik, S. (2011). Teacher job satisfaction and motivation to leave the teaching profession: Relations with school context, feeling of belonging, and emotional exhaustion. Teaching and teacher education, 27(6), 1029-1038.

Van Maele, D., \& Van Houtte, M. (2012). The role of teacher and faculty trust in forming teachers' job satisfaction: Do years of experience make a difference? Teaching and teacher education, 28(6), 879889.

Wibowo, I., Riana, G., \& Putra, M. S. (2015). Pengaruh Stres Kerja Terhadap Kepuasan Kerja Dan Komitmen Organisasional Karyawan. E-Jurnal Ekonomi dan Bisnis Universitas Udayana, 4(2), 125-145.

Zulkifli, M., Darmawan, A., \& Sutrisno, E. (2014). Motivasi Kerja, Sertifikasi, Kesejahteraan dan Kinerja Guru. Persona: Jurnal Psikologi Indonesia, 3(02). 